\title{
Daniël 2 as satire
}

\author{
Author: \\ Marius $\mathrm{Nel}^{1}$ \\ Affiliation: \\ ${ }^{1}$ School of Biblical Studies \\ and Ancient Languages, \\ North-West University, \\ Potchefstroom Campus, \\ South Africa \\ Correspondence to: \\ Marius Nel \\ Email: \\ marius@tabernadei.co.za \\ Postal address: \\ PO Box 12373, Bendor Park \\ 0713, South Africa \\ Dates: \\ Received: 08 Nov. 2010 \\ Accepted: 14 Jan. 2011 \\ Published: 23 Jan. 2012 \\ How to cite this article: \\ Nel, M., 2012, 'Daniël 2 \\ as satire', HTS Teologiese \\ Studies/Theological Studies \\ 68(1), Art. \#979, 7 pages. \\ http://dx.doi.org/10.4102/ \\ hts.v68i1.979
}

C 2012. The Authors. Licensee: AOSIS OpenJournals. This work is licensed under the Creative Commons Attribution License.
Daniel 2 as satire. Readers use intuitive and acquired knowledge about genres in interpreting what they read and hear, underlining the importance of establishing the genre of a specific piece of literature. The genre of the tales in the Book of Daniel (1-6) has been researched over a long period, without leading to a consensus. In this article it is suggested that the genre of the tales in Daniel may be described in terms of satire, used as a means of resistance to foreign political oppression. Especially humor and irony are utilised in the satire to describe Jewish perception of the oppression and oppressor, and to make suggestions for acting in the crisis situation of Antiochus' suppression of the Jewish religion. This is demonstrated in terms of the tale in Daniel 2, and specifically in the depiction of the indirect characters in the tale - the God of the Jews in Daniel 2, in contrast to the powerlessness of the gods of the mighty heathen king. In this way the true nature of Jewish oppression is pictured in a humorous way when the Babylonian gods are at the mercy of the Jewish God.

\section{Genre}

Die bepaling van genres kom ooreen met die verdeling van plante en diere in spesies, genusse, families, en so meer. Die skopus van 'n spesifieke ondersoek na genre, wat ooreenkomste en verskille binne dieselfde soort literatuur wil vasstel, kan omvattend en spesifiek wees. Literatuur kan breedweg in narratiewe en gedigte, of prosa en poësie verdeel word. Narratiewe bestaan uit geskiedskrywing, fiktiewe vertellings, mites en legendes, en toegepaste literatuur (Hambidge 1992:148). Genrestudie behels dat die navorser 'n literêre werk binne groter relasionele kontekste plaas, totdat die konteks alle literatuur omsluit.

Die wêreld wat die verteller in 'n literêre werk skep, is 'n hipotetiese wêreld, en om dié wêreld te verstaan, moet die leser na die teks self luister. 'n Nuttige hulpmiddel om die teks te ontsluit, is om in werke van dieselfde genre na wenke te gaan soek hoe om die genre te verstaan. Om die Bybel as literatuur te lees, beteken dat dit in die groot raamwerk van literatuur geïnkorporeer word. Die Bybel word dan bestudeer in terme van sy verhouding met die ander dele van die geheel van literatuur (Berlin \& Brettler 2004:2084-5). Om 'n werk binne die Bybel as literatuur te verklaar, beteken dat die genre daarvan bepaal word, en dat dit in terme van die konvensies van dié genre geïnterpreteer word.

Elke teks gebruik individuele uitdrukkings en stylelemente. Wanneer navorsers so 'n teks se genre vasstel, dui hulle daarmee aan dat die teks strukture van inhoud en uitdrukking in gemeen met ander tekste het. ${ }^{1}$ Die genre word dan aan 'n Sitz im Leben gekoppel, 'n spesifieke kommunikasiesituasie waardeur die genre (of verskeie) genres aan mekaar verbind word. Deur die Sitz im Leben te ontdek, word dit moontlik om die genre te herken, die funksie daarvan te omskryf en die kriteria vir die interpretasie van die tekste binne die genre af te lei (Rendtorff 1985:77-78). ${ }^{2}$

Verhale in die Ou Testament is meestal kort, veral as dit met ander antieke literêre werke van byvoorbeeld Plato, Krito en Phaedo vergelyk word (Deist 1992:358). In meeste gevalle lees die leser die verhale in sigself sonder om veel agtergrond uit die konteks te versamel. Die einde

1.In die woorde van Todorov (aangehaal in Hambidge 1992:148): 'A genre is a class of texts which has a historically attested existence. It is an ambiguous entity, on the level of analysis: on the one hand it is empirical, since it can be situated in time and space, its exemplifications can be listed, testimony as to its relevance for producers (writers) and receivers (readers) of texts can be collected; on the other hand it is theoretical, because it should be possible, ideally (that is, if the descriptive apparatus of poetics were rich enough) to deduce the genres from the combinatory possibilities of the characteristic features of literary discourse.'

2.Die belangrikste basiese vorms van narratiewe is, volgens Rendtorff (1985:85), mites, volksverhale, sages en legendes. Legendes word dikwels van sages onderskei op grond van die inhoud daarvan. As die karakters, plekke of gebeure wat sentraal tot die vertelling is, godsdienstige belang het, word dit as'n legende beskryf (Eissfeldt 1974:33-47). So ook Culley (1992:21) wat skryf: 'Like legend, biblical narrative moves on the human plane and involves presumed historical figures; but like legend, it also has a divine or supernatural plane narrative moves on the human plane and involves presumed historical figures; but like legend, it also has a divine or supernatural plane volgens dié definisie as legendaries beskou, as die naaste Bybelse voorbeeld van die middeleeuse legendes. Eissfeldt (1974:46-47) beskryf die Daniëlverhale as 'martyr-legend', waar 'martelaar' in die oorspronklike betekenis van 'getuie' verstaan word. Dié legende beskryf die Daniëlverhale as 'martyr-legend', waar 'martelaar' in die oorspronklike betekenis van 'getuie' verstaan word. Dié legende
gee baie ruimte aan die opstanding van die dode. 'In these stories individuals are threatened with death for their faith' (Eissfeldt gee baie ruimte aan die opstanding van die dode. 'In these stories individuals are threatened with death for their faith' (Eissfeld
1974:47). Ander soortgelyke martelaarlegendes word in Ester, 2 Makkabeërs 6-7 (wat herhaal word in 4 Makk) en 3 Makkabeërs gevind. 
daarvan is ook in meeste gevalle 'geslote', wat beteken dat die kalmte herstel word. Die skrywer laat min aan die leser se verbeelding oor (Licht 1978:27).

\section{Literêre genre van die Daniëlverhale Daniëlverhale se genre}

Die vraag na die genre van die Daniëlboek as 'n geheel, en van die verhale in die eerste ses hoofstukke, het as een van die sentrale kwessies in moderne navorsing na vore gekom (Collins 1984:28). Daar is redelike eenstemmigheid dat die verhale in die eerste ses hoofstukke materiaal bevat wat ouer as die materiaal in Daniël 7-12 is. Die verhale oor Daniël en sy drie vriende kom in verskeie opsigte ooreen met 'n aantal Bybelse en nie-Bybelse verhale, soos die verhale van Josef en Ester; die Assiriese Agikarstorie; Tobit; Judith; Daniël en Susanna; Daniël, Bel en die slang; en die verhaal van Darius se drie lyfwagte in 1 Esdras 3:1-4:63 (Nickelsburg 1972:48-58; Humphreys 1973:211; Collins 1975:219; Hartman \& DiLella 1978:55-61; Porteous 1979:16).

Navorsers stem oor dié sake ooreen, maar wanneer dit kom by ' $n$ bepaling van die genre van die Daniëlverhale en die verwante literatuur, is daar weinig ooreenstemming. Een van die grootste probleme is dat daar nie 'n standaard genreindeling bestaan wat deur alle navorsers aanvaar word nie (Kirkpatrick 2005:5-7).

Die Daniëlverhale se genre is al beskryf as:

- Haggadiese verhale (Bentzen 1952:11; LaCocque 1979:26).

- Godsdienstige of populêre romanses (Heaton 1956:32-47; Gammie 1976:193).

- Wysheidsverhale (Scott 1971:95; Nickelsburg 1972:55).

- Hofverhale (Humphreys 1973:220; Collins 1975:219; Niditch \& Doran 1977:179).

- Wonderwerkverhale (Hengel 1974:111).

- Aangepaste martelaarsverhale (Hartman \& DiLella 1978:58; Porteous 1979:55)

- Midrasj-verhale (Hartman \& DiLella 1978:55).

- Hoflegendes (Collins 1984:42; 1985:134).

- Komedie (Good 1985:47-56).

- Prenovelistiese Menippeaanse satire (Valeta 2008:1).

Daar is duidelik tussen verskeie van die klassifikasies duplisering en ooreenkomste. Dit hang saam met die gebrek aan 'n standaard vormkritiese genreterminologie, soos hierbo genoem.

Die meerderheid van navorsers meen die verhale in Daniël 1-6 is deel van die belangrike komponent van Bybelse literatuur wat algemeen as wysheidsliteratuur bekend staan. Wysheidsliteratuur is ' $n$ literatuursoort wat wyd in die antieke Nabye-Ooste voorkom, en bevat instruksies vir 'n suksesvolle lewe binne die gekompliseerdheid van daaglikse bestaan (Van der Toorn 2007:21). Wysheid bestaan uit twee tipes: spreukagtige wysheidsgesegdes en spekulatiewe of mantiese wysheid wat na die sin van die lewe vra, en die verhouding tussen God en die individu ondersoek. Spekulatiewe wysheid is altyd empiries en prakties, en nooit bloot teoreties nie (Crenshaw 2007:93). Job en Prediker is voorbeelde van dié wysheidstipe, mantiese wysheid (Douglas 1962:1334-1335). Die Daniëlverhale tel ook daaronder. Die Daniëlskrywer gee instruksies aan Diasporajode hoe om hulle lewe in ' $\mathrm{n}$ vreemde konteks tussen nie-Jode in te rig (Humphreys 1973:211).

Om die Daniëlverhale in verdere kategorieë te beskryf, maak eers sin as die kategorieë verder ontwikkel is en 'n hulpmiddel word waarmee die betrokke teks beter verstaan kan word. Om die Daniëlverhale as wysheidsliteratuur te lees, verskaf aan die navorser egter alreeds hulpmiddels wat ontwikkel is om sowel $\mathrm{Ou}$ Testamentiese as buite-Bybelse wysheidsliteratuur te verstaan.

Van die talle subklassifikasies wat gebruik word om die verhale binne die wysheidskategorie te plaas, is die mees gekose die hofverhaal wat binne die breër verband van wysheidsliteratuur figureer. Die verhaal van die howeling is volgens Humphreys (1973:220) gekenmerk deur 'n patroon of struktuur wat deur alle verhale gedeel word wat tot die tipe behoort (vgl. Lucas 2002:65). Daar is vyf basiese elemente in die patroon:

- In die sentrum van die verhaal is 'n howeling wie se kwaliteite uitstaande is en wat gou daarvoor erkenning kry.

- Hierdie howeling vind sy plek in die koninklike hof van die dag.

- Die lewe van die howeling word nou bedreig deur die bose sette van ander howelinge of deur omstandighede aan die hof.

- Die howeling is in staat om die bedreiging te oorkom deur die omstandighede te oorwin of die sette van kollegas te omseil, en hy word weer in ere aan die hof herstel.

- Die howeling word tot 'n hoër rang verhef en beloon, terwyl sy vyande gestraf word (Humphreys 1973:217).

Humphreys (1973:217) onderskei twee subtipes, 'verhale van hofkonflik' ('tales of court conflict') en 'verhale van hofgeskil' ('tales of court contest'). Die verskil tussen die twee subtipes lê in die manier waarop die derde en vierde elemente van die basiese vorm gerealiseer word. Die bron van die gevaar wat die howeling bedreig, asook die wyse waarop die gevaar oorkom word, bepaal of 'n gegewe howelingverhaal na hofkonflik of hofgeskil verwys.

Elke subtipe het sy eie skema of patroon. In hofgeskille kom 'n geveg tussen die howeling en sy vyandige kollegas voor, waarin die howeling wen, en dan vir sy sukses beloon word, terwyl die ander hulle straf kry. Die verhaal sluit met die erkenning van die suksesvolle held. Daniël 2, 4 en 5 word deur Humphreys (1973:219) hieronder geplaas. ${ }^{3}$

Collins (1975:219) meen weer drie motiewe of klemtone is in Daniël 1-6 relevant:

- Dit beklemtoon die wysheid of vermoë van die howeling.

- Dit fokus op die drama van gevaar of vernedering wat deur uitredding gevolg word.

3.En so ook die deel van die Josefverhaal wat in Genesis 40-41 voorkom. 
- Dit word gebruik as instrument om die boodskap van die howeling weer te gee.

Die eerste groep identifiseer Collins met die verhale van hofgeskille van Humphreys, en die tweede groep met Humphreys se verhale van hofkonflik. Die verhaal in Daniël 2 behoort aan die eerste groep. Die klem val op die wysheid van Daniël en sy God, en die werklike inhoud van die droom word gerelativeer daartoe (Collins 1975:220).

Die studie van hofverhale is verryk deur die artikel van Niditch en Doran (1977:179-193) wat slegs op Daniël 2, Genesis 41 en Agikar 5-7 konsentreer en bevind dat dié drie een literêre tipe deel (Niditch \& Doran 1977:179). Niditch en Doran (1977:180) stel voor dat die beskrywing van 'n literêre tipe op beide inhoud en struktuur gebaseer moet word. Hulle benadering toon ooreenkoms met dié van Aarne en Thompson (1961), waarin die skrywers duisende volksverhale ooreenkomstig hul inhoudselemente (motiewe) en die struktuur van hul inhoudselemente (die rangskikking van elemente) versamel en kategoriseer (Niditch \& Doran 1977:180).

Niditch en Doran (1977:180) noem dat die literêre tipe of vorm van die verhale in Daniël 2, Genesis 41 en Agikar 5-7 reeds deur Aarne en Thompson beskryf is, as volksverhale oor wyse manne (Tipe 922) wat handel oor 'clever acts and words'. Volgens Aarne \& Thompson is daar vier primêre komplotgebeure in verhale wat tot Tipe 922 hoort. Elkeen van hierdie primêre komplotgebeure is saamgestel uit 'n kombinasie van motiewe van aksie, karakter, agtergrond, en so meer. Die vier elemente is:

- 'n Persoon van 'n laer status word geroep voor 'n persoon van hoër status om te antwoord op moeilike vrae of om 'n probleem wat besondere insig vereis, op te los.

- Die persoon van hoër status stel die probleem wat niemand anders kon oplos nie.

- Die persoon van laer status los die probleem op.

- Die persoon van laer status word vergoed daarvoor (Niditch \& Doran 1977:180).

Binne dié primêre gebeure bestaan verskeie variasies op die basiese motiewe, wat deur die outeurs nuanses genoem word.

Niditch en Doran gebruik die patroon of skema van AarneThompson as 'n maatstaf waarteen hulle die drie verhale meet, omdat hulle wil beklemtoon dat die inhoud sowel as inhoudstruktuur belangrik in die genreklassifikasie van 'n literêre werk is.

Waarin verskil die drie verhale van die verhale wat oorspronklik onder Tipe 922 beskryf is? Die hoofbron van variasies tussen die verhale lê in die nuansering van die basiese motiewe van die verhaaltipe. Nuanses is belangrik omdat dit die besondere etos agter die gebruik van die betrokke tipe verraai. Die nuanses van elke verhaal moet afsonderlik beoordeel en beskryf word.
Nadat die navorsers die drie verhale vir hul nuanseringe ondersoek het, kom hulle tot die gevolgtrekking dat die Agikarverhaal die naaste aan die tradisionele weergawe van Tipe 922 kom. Agikar 5-7 is kultureel genuanseer, maar het dieselfde tema as die tradisionele verhale in Tipe 922. Dit bevat geen besondere godsdienstige of politieke nuanses nie. Genesis 41 is, soos Agikar 5-7, kultureel genuanseer. Maar Genesis 41 het ook 'n godsdienstige nuanse wat dit van die Agikarverhaal sowel as van tradisionele Tipe 922-verhale onderskei. Die godsdienstige nuanse lê in Josef se vermoë om die farao se drome uit te lê. Dié vermoë is deur God aan hom verleen. Hierdie nuanse kom nie in die Aarne-Thompsonkatalogus onder Tipe 922 of in enige van die gelyste verhale voor nie. Dit verteenwoordig 'n 'less traditional use' van Tipe 922 (Niditch \& Doran 1977:187).

Die verhaal in Daniël 2 staan selfs nog verder van die tradisionele weergawe van Tipe 922 as Genesis 41. Hier word die basiese patroon van Tipe 922 slegs gebruik as raamwerk vir 'n belangriker tema oor die openbaring van die goddelike wil (Niditch \& Doran 1977:187). Naas die tipiese motiewe van Tipe 922, bevat Daniël 2 nog twee aksiemotiewe (gebed en die antwoord van gebed) en een karaktermotief ('n goddelike helper) wat vreemd aan Tipe 922 is. Hierdie addisionele motiewe het geen plek in die tradisionele wysheidsverhale waarin wyse manne op hulle eie slaag nie (Niditch \& Doran 1977:190). Motiewe van versoeke om hulp en die voorsiening van hulp deur 'n helper is eerder kenmerkend van die Aarne-Thompson tipes 300-749. In dié gevalle is die helper en helpende aksie gewoonlik magies van aard, maar nie goddelik nie. Die goddelike (teenoor die magiese) kwaliteit is 'n kulturele nuanse op die basiese motief van hulp, maar die motief bly steeds vreemd aan Tipe 922.

Niditch en Doran (1977:193) kom dan tot die gevolgtrekking dat die tradisionele wysheidsverhaal in Daniël 2 substansieel hervorm en herbenut is, alhoewel dit nie volledig verlore gegaan het nie. In terme van die struktuur van motiewe volg Daniël 2 die tradisionele orde, maar voeg ook motiewe of inhoudselemente by wat nie normaalweg in die patroon voorkom nie. Die tradisionele eenvoudige tema oor wysheid en sukses verdwyn in die agtergrond as Daniël 2 eerder wys na 'n nuwe vorm waarin die interpretasie van droomsimbole die aanvaarbare norm word om goddelike openbaring te ontvang.

Davies (1985:54) het nie 'n probleem om die verhaal as 'n hofverhaal te beskryf nie, maar meen dat dit nie soos ander hofverhale die hooffunksie het om te vermaak nie. Die doel van die verhaal in Daniël 2 is om te bemoedig. Die verhaal word vertel teen die agtergrond van potensiële of werklike konflik tussen die Jodedom en die heidendom. Daarom is die tema daarvan 'n voorstel vir 'n geskikte lewenstyl vir die diaspora (Humphreys 1973:222-223). ${ }^{4}$

4.Daniël se verhale het hul oorsprong in die na-eksiliese diaspora en 'present a style of life for the diaspora Jew, which affirms most strongly that at one and the same time the Jew can remain loyal to his heritage and God and yet can live a creative, time the Jew can remain loyal to his heritage and God and yet can live a creative,
rewarding, and fulfilled life precisely within a foreign setting, and in interaction with it... (Humphreys 1973:223)'. 


\section{Daniëlverhale as satire}

Deur die verhale as hoflegendes te beskryf, openbaar egter nie genoeg detailinligting oor die doel daarvan nie. Die Daniëlverhale is weerstandsliteratuur, soos onder andere Smith-Christopher (1993:339) en Collins (2002:11) betoog. Die weerstand teen onderdrukking in die verhale is meer subtiel as wat in die visioene voorkom, en word in die verhale deur satire gedryf.

Satire kan verwys na 'n aanval op die onbevredigende toedrag van sake, 'n militante woordkuns waarin sowel die outeur as lesers in verset kom teen 'n werklikheid wat hulle as bedreigend ervaar (Pretorius 1992:464). In die geval van die Daniëlboek was dit gevaarlik om die maghebber van die dag, Antiogus IV Epifanes, te kritiseer, en daarom word satire en verhale wat in ander kontekste afspeel, benut om die Jood se belewenis van die situasie te beskryf, maar ook tot aksie op te roep:

Die eintlike appèl wat die satire maak, soos enige ander woordkunswerk, lê in sy literêre meriete: die buitengewoon knap ontginning en ordening van die materiaal, die kundige hantering van tegniese middele, die verrassend oorspronklike perspektief op die bekende ... Nie wat gesê word nie, maar hoe dit gesê word, bepaal die appèl wat die satire op die leser/gehoor maak. (Pretorius 1992:465)

'n Belangrike element van satire is humor. Die Daniëlverhale, en spesifiek Daniël 2, is al beskryf as komedie (Good 1985:4756). Humor is uiters moeilik om te definieer omdat dit kultureel en histories relatief is, alhoewel humor as 'n feit ' $n$ antropologiese konstanteis(Berger 1997:10). Humor is verbind aan drie teorieë: dit is daarop gerig om emosionele spanning, of inhibisies oor verbode dinge en taboe-onderwerpe te verlig; dit is daarop gerig om inkongruïteit, of frustrasie van verwagtinge te verlig wanneer aanvaarbare konseptuele patrone omvergewerp word; en om meerderwaardigheid, of degradasie te bevestig (Feinberg 1971:3-15). Martin (1998:1560) stel 'n holistiese driedimensionele model voor wat die kognitiewe, emosionele en motiveringsoorsake van humor erken en beskryf.

Die verhaal in Daniël 2 benut humor om die onderdrukkende politieke magte van die dag te weerstaan in 'n tyd waarin dit moontlik te gevaarlik was om konings en koninkryke by die naam te noem. Satire verleen hom uitstekend daartoe om die spot te dryf met die maghebbers van die dag wat vertellers van verhale se lot kon bepaal, maar wie se reputasie nie stand kon hou voor die storievertellers nie. En die karakters word telkemale in verband met hulle onderskeie gode gebring, sodat die verhale op verskillende vlakke - 'n voortdurende wisseling tussen die natuurlike en bonatuurlike - afspeel.

Om satire te definieer, is net so moeilik as om 'n algemeen geldende definisie van humor te bied (Harris 1992:357-361). Satire kom in komedies en tragedies voor, maar kan nie so maklik geëien word nie en kan dus oor kulturele en historiese grense heen maklik misgekyk word. Van antieke tye af is satire beskryf in terme van die vorm, doel of morele funksie.
Twee basiese vorme kom voor in poësie en prosa, soos in klassieke Rome en Elizabethaanse Engeland vervolmaak (Griffin 1994:12-24).

Daniël 2 benut satire op 'n literêr gesofistikeerde en polities genuanseerde wyse (Valeta 2008:3). In die verhaal word die teenoorstaande karakters telkemale in terme van hulle onderskeie gode gesitueer, en bepaal die teologiese insigte wat hieruit groei, die betekenis van die verhaal vir die eerste lesers. Die uitbeelding van God en die gode in die verhaal word beïnvloed deur wat die verteller wil sê: dat JHWH in beheer van die gang van sake is. Vervolgens word na aspekte van die uitbeelding van die Joodse God en die Babiloniese gode, as bepalende faktor vir die optrede van die Joodse en Babiloniese karakters, gekyk in 'n poging om die satiriese element in Daniël 2 te demonstreer.

\section{Daniël 2 as satire en die uitbeelding van God en die gode}

Die hipotese is dat die verhaal in Daniël 2 satiries is. In die laaste afdeling word die verhaal ontleed in terme van die indirekte karakters, Israel se God en die Babiloniërs se gode, om op satiriese elemente te wys wat die verhaal kenmerk.

Waar pas God in Daniël 2 in? God is die helper wat aan die held die nodige inligting verskaf. Die hulp is ietwat verwyder van die probleem deurdat God indirek te werk gaan - God verskaf die benodigde inligting aan Daniël, wat weer die inligting aan die koning deurgee. Tog bly God die noodsaaklike faktor wat die held in staat stel om te slaag (Valeta 2008:72). In Daniël 1:2 word God op dieselfde wyse beskryf, as die Een wat Jerusalem in Nebukadnesar se hand plaas. Dit is as't ware asof die verhaalkorpus sy bestaan aan dié God wat in die geskiedenis inmeng, te danke het (Burden 1987:200).

Verwysings na God is volop in die verhale. 'Daniël is die hoofkarakter, maar "agter die skerms" is dit eintlik God. Daniël is maar net sy "dubbelspeler" (Burden 1987:200).' In 2:23 is dit God wat wysheid en insig aan die vier Jode gee. Die uitleg van die koning se droom (2:23) asook die droom (2:28) en die koning se mag en gesag (2:37) kom van God. Die koning erken daarom nie slegs vir Daniël as die held nie, maar ook Daniël se God as 'die grootste van al die gode, Hy heers oor die konings (Bybel 1983 vertaling van "God van die gode en Here van die here" ${ }^{\prime \prime}$ '

Watter aktiewe rol speel God in die verhale? Is God nie die een wat as werklike opponent geld nie? Hy het immers veroorsaak dat Daniël en sy vriende, saam met die Jode, in 'n vreemde land sit. Speel God meer as een rol? In feëverhale figureer die noodlot dikwels in dieselfde rol as wat God in Bybelse verhale vervul (volgens Vladimir Propp se analise; vgl. Milne 1988:211-215). Maar die God van die held is in Daniël 2 'n werklike karakter wat ' $n$ wesenlike rol in die verhale vervul. God is nie slegs 'n toestand nie. Milne (1988:220) meen dat as die verwysings na God uit dié verhaal verwyder word, dit'n wesenlike verskil sal maak. Die droom en sy uitleg sal nooit bekend word nie, omdat die verteller 
dit herhaaldelik beklemtoon dat 'n mens dit verseker nie kan doen nie.

Die insluiting van God as aktiewe, deelnemende karakter is 'n eienskap van Bybelse verhale. Dit is dié aspek wat Bybelse verhale onderskei van ander verhale, soos die Agikarverhaal of feëverhale. Tog speel God nie dieselfde rol as Nebukadnesar of Daniël, of 'n ander menslike figuur nie. White (1978:169172) meen God en die Babiloniese gode vervul 'n rol iewers tussen die eksterne posisie van die verteller en die interne posisie van die karakters. Dit verleen ' $n$ heterogene dimensie aan die basis van die narratiewe struktuur wat direk die oppervlakte-struktuur van die vertelling beïnvloed. ${ }^{5}$

In Proppiaanse terme is God se rol motiverend van aard ('the notion of motivations'). God inisieer die motiewe van karakters wat tot hul dade en besluite lei. In Daniël 1 en 2 is God die Een aan wie aksies, vermoëns en kwaliteite toegeken word. God is die uiteindelike oorsaak van alles wat in die verhaal gebeur. Tog lyk dit asof die werklike beweging in die verhaal sonder God se direkte inmenging plaasvind, behalwe in die geval van die oplossing van die moeilike taak om die droom uit te lê.

Die narratief word doelbewus humoristies aangebied om die koning en sy gode se gesag te ondermyn, en die verteller doen dit deur die koning wat sy gode verteenwoordig, se gesag te kontrasteer met God se gesag. Daarom vind die koning dat sy koninklike oplossings, met verwysings na die gode se onmag, nie sy probleme oplos nie, en hy moet op buitestaanders staatmaak om sy probleme op te los, en dan ook nog op ballinge in sy ryk, eerder as sy eie wyse manne. Tweedens beskryf die verteller hoe die Hebreeuse God die koning se behoeftes moet vervul omdat sy eie gode dit nie kan doen nie, wat die idee van die koning se absolute gesag ondermyn. Derdens beskryf die hoofstuk in toenemende mate die absurde gedrag van die koning, wat vir die lesers lagwekkend moes voorkom. Vervolgens gebruik die verteller woordspel om die dubbelsinnigheid en speelsheid in die narratief te beskryf. En laastens dui ironie en oordrywing aan dat die verteller besig is om met die mees geërde koning van sy dag gek te skeer (Valeta 2008:73).

Interessant dat die aantal karakters wat by die intrige betrokke is, telkens slegs twee is. Die verteller beperk doelbewus die aantal, sodat die leser se aandag nie afgelei word nie. Die verteller wil die leser op 'n paar fokuspunte binne die toneel laat konsentreer. Die partye in Daniël 2 is die koning en die wyse manne, die koning en die hoof van die lyfwag, die koning en Daniël, en in die laaste instansie en agter die skerms, God en die gode van Babel.

Die episode van die nag wat in verse 17-23 beskryf word, is die kritiese element wat die verhaal uniek maak tussen soortgelyke bekende verhale. Die daad van gebed, die antwoord op die gebed en die teenwoordigheid van God wat hulp verskaf, is motiewe wat die verhaal se fokus wegdraai van menslike wysheid (Lucas 2002:78).

5.White (1978) verwys spesifiek na die optekening van direkte spreke van God. In die twee verhale kom dit nie voor nie, maar die beginsel bly dieselfde.
Wanneer die vier Jode bid, gebruik die skrywer die teofore Hebreeuse name van die Judeërs (Burden 1987:201). Dit is gepas in die konteks van geloof en gebed, volgens Baldwin (1978:89). Die gebruik van die Babiloniese en Hebreeuse name openbaar 'n fyn ironiese spel by die verteller, wat daarmee die almag van God teenoor die mag van die gode afspeel (Davies 1985:54).

Daniël se oproep aan sy vriende het te doen met die belydenis wat later in vers 28 voor die koning gelewer word. Daniël sê: 'Ons kan nie die droom verklaar nie, maar daar is ' $n$ God in die hemel wat geheime kan openbaar.' Die woord wat die skrywer vir 'geheim' (raz) gebruik, kom van die Persiese woord vir misterie of geheim, en word agt keer in die hoofstuk gebruik. In die apokaliptiek verwys dit na die goddelike plan en doel met die geskiedenis (Helberg 1994:33). 'Uitleg' (peshar) kom dertien keer in Daniël 2 voor. Die twee woorde is nou geïntegreer, sodat die een nie sonder die ander verstaan kan word nie. In verse 18, 19, 27-30 en 47 word raz gebruik om na die droom en sy uitleg te verwys, sonder om die tweede element te noem (Lucas 2002:72).

Die skrywer kontrasteer die ironiese verskil tussen Nebukadnesar en Daniël in dié verse duidelik: Nebukadnesar raadpleeg mense, terwyl Daniël God raadpleeg. Dat God onbeperk in mag en kennis is, staan sentraal tot die posisie en doel van die skrywer. Dit bepaal die gesigspunt van die werklike skrywer.

Daniël ontvang die geheim van die droom in 'n naggesig (v. 19). Die visioen is ' $n$ meer direkte vorm van openbaring, 'n hoër en beter medium van openbaring as 'n vae droom (Alobaidi 2006:440). So dryf die verteller die kontras tussen die koning en Daniël verder: Nebukadnesar sien 'n droom wat hom ontstel, omdat dit 'n openbaring van God is, maar hy moet rondsoek na die uitleg, terwyl Daniël direk van God hoor.

Die volgende inligting word in die lied oor God se rol in die verhaal openbaar (Fewell 1991:29):

- Die goddelike kan openbaar wat geen mens ken nie.

- God openbaar Hom aan mense, téén die teologie van die wyse manne in wat sê dat die gode nie onder die mense woon nie. Die 'God van die hemel' word die 'God van my vaders'.

Opvallend is die gebruik van name vir God in die hoofstuk. Nêrens het God 'n persoonlike naam nie. Alle name wat vir God gebruik word, word gebore uit verhoudings met God (Burden 1987:201).

Daniël daag dan by Arjok op met die versoek dat hy na die koning geneem word, vir wie hy die droom vertel. Daniël beklemtoon in sy antwoord aan die koning dat niemand die droom kan vertel of uitlê nie. Valeta (2008:76) sien hierin die ironie tussen menslike en goddelike mag, as slegs God die misterieuse droom kan verklaar. ${ }^{6}$ Die verteller gebruik die

6.'Human power is always relative, being subject to God who bestows it. God is the only one who independently exercises power (Joubert 1979:217).' 
verwysing na die wyse manne slegs om te wys op die mens se onvermoë om die geheim te verklaar. Dit dien as kontras met Daniël se God, die God van die hemel, wat in staat is om die uitleg te gee (Lucas 2002:72). En God is nie soos die gode net met God self besig nie. God woon onder mense, al is God se tempel in Jerusalem deur dieselfde koning verwoes en lê sy tempelinstrumente in die skatkamers van Marduk. God bemoei Hom met die belange van mense. ${ }^{7}$ God is die God wat nie slegs die toekoms ken nie, maar dit ook bepaal (Collins 2002:11). Dit is nie net die duisternis wat by God is nie; die lig woon ook by God (v. 22).

In Nebukadnesar klop die hart van 'n imperialis. Hy is 'n wêreldveroweraar. Hieruit word die droom gebore, wat waarsku: alhoewel Nebukadnesar'n hoë posisie beklee, is hy nie allerbelangrik nie. Hy is daar omdat God hom daar gestel het (Lucas 2002:78).

Die waardevolle beeld met sy blink voorkoms kontrasteer direk met die vaalheid en onindrukwekkendheid van die steen wat ooglopend ook baie minder waarde het (Good 1985:51), wat die ironiese kontras tussen menslike en goddelike mag uitbeeld. Die verskil met dié klip is dat dit nie deur 'n mensehand opgetel is nie. Die vyfde koninkryk is nie 'n 'goddelike' koninkryk nie, maar 'n (aardse) ryk wat deur God opgewek is (Lucas 2002:80). Die hoof van goud is egter ook deur God opgewek, en so ook die ander ryke wat as instrumente van God op een of ander stadium beskryf word.

Die skrywer gebruik 'n dubbele dimensie in sy perspektief op wêreldgebeure as hy 'n kousale verband tussen die onsigbare en die sigbare sien. Aardse gebeure is nie bloot die resultaat van politieke, ekonomiese, maatskaplike en ander faktore nie. Aardse maghebbers en wêreldgebeure kan beter verduidelik word aan die hand van die werklikhede van die onsigbare wêreld (Caragounis 1993:396). Dit is dié werklikheid wat die gang van die geskiedenis bepaal, en wat toon dat God bemoeienis met sy mense wat deur goddelose magte verdruk word, maak (Lucas 2002:79).

Die verhaal sluit af wanneer ironie op die spits gedryf word. Met heerlike humor word Daniël, die Judese gevangene, dié een wat aan die vreemde hof die wyse manne die loef afsteek (Collins 2002:12). Hy word die heerser, ontvang die geskenke, en die groot koning wat Daniël se volk onderwerp en hulle God saam in ballingskap weggevoer het, buig voor 'n verteenwoordiger van dié God. Die koning erken dat Hy God van die gode en Koning van die konings is (v. 47). En dit alles, omdat Daniël in die naam van dié God die droom kan vertel, en 'n uitleg daarvoor bied (Kirkpatrick 2005:67).

Dit lyk nie of die koning die uitleg van die droom snap nie. Daniël voorspel immers dat die Babiloniese ryk tot 'n einde gaan kom, en dat God se volk oor die wêreld gaan regeer. Die verteller skep 'n ironiese kontras tussen die kennis wat die koning het, en wat Daniël weet (Venter 1993:1017). Of

7.In dié sin skryf Smith-Christopher (2002:57) dat die koning se droom nie die drome van 'n Babiloniese koning is nie, maar die fantasieë van 'n Joodse outeur, die 'dreams of the disenfranchised.' die koning hom werklik aan die God van Daniël (in die verhaalwêreld) steur, is te betwyfel. Dit lyk of hy net bly is dat hy die kop van goud is (Baldwin 1978:94). Niks in sy verdere optrede dui daarop dat hy skielik hom tot dié God bekeer het, of die etiek wat deur dié God voorgeskryf word, aanvaar nie (Young 1949:81).

Porteous (1979:51) meen dat die skrywer hier fyn humorsin aan die dag lê: 'The Jew who was so often in die position of the inferior liked to indulge in the fantasy of having the tables turned on occasion.' Hoeveel moed sou 'n tweede-eeuse Jood wat die dood aan die hand van 'n volksvyand in die gesig staar, nie put uit 'n verhaal wat vertel hoe die volksvyand voor die Jood buig nie!

\section{Sintese}

Lesers begryp 'n verhaal, en pas (dikwels intuitief) verskillende reëls toe, aan die hand van die inligting wat hulle oor die genre daarvan het. Dit impliseer dat dit belangrike waarde het om oor die genre van 'n bepaalde verhaal te besin. Oor die Daniëlverhale se genre is baie geskryf sonder dat konsensus oor ' $n$ vasstelling daarvan bereik is. In dié artikel word voorgestel dat Daniël 2 as satire gelees word, wat met behulp van veral ironie en humor weerstand teen politieke onderdrukking bied, en optrede daarteen aanmoedig. Die uitbeelding van God en die gode in Daniël 2 is ondersoek, en dit toon die satiriese elemente van 'n verhaal wat deur humor en ironie gekenmerk word.

\section{Erkennings \\ Mededingende belange}

Die outeur verklaar dat hy geen finansiële of persoonlike verbintenis het met enige party wat hom nadelig kon beïnvloed in die skryf van hierdie artikel.

\section{Literatuurverwysings}

Aarne, A. \& Thompson, S., 1961, The types of the folktale: A classification and bibliography, 2nd edn., Folklore Fellows Communications, Helsinki. (Folklore Fellows Communications, no. 148.)

Alobaidi, J., 2006, The Book of Daniel: The Commentary of R. Saadia Gaon, Peter Lang, Bern.

Baldwin, J.G., 1978, Daniel: Tyndale Old Testament commentaries, Inter-Varsity, Leicester.

Bentzen, A., 1952, Daniel: Handbuch zum Alten Testament, 2. Auflage, Mohr, Tübingen. Berger, P., 1997, Redeeming Laughter: The Comic Dimension of Human Experience, W. de Gruyter, New York.

Berlin, A. \& Brettler M.Z. (eds.), 2004, The Jewish Study Bible, Oxford University, Oxford

Berlin, A. \& Brettler, M.Z., 2004, s.v., 'The modern study of the Bible', in A. Berlin \& M.Z. Brettler (eds.), The Jewish Study Bible, pp. 2084-2096, Oxford University, Oxford.

Burden, J.J., 1987, 'Die boek Daniël', in J.J. Burden \& W.S. Prinsloos (reds.) Tweegesprek met God: Die literatuur van die Ou Testament, deel 3, pp. 195-220, Tafelberg, Kaapstad.

Burden J.J. \& Prinsloo, W.S., 1987, Tweegesprek met God: Die literatuur van die Ou Testament, Tafelberg, Kaapstad.

Caragounis, C.C., 1993, 'History and supra-history: Daniel and the four empires', in A.S van der Woude (ed.), The book of Daniel in the light of new findings, pp. 387-398, Leuven University, Leuven.

Clifford, R.J. (ed.), 2007, Wisdom Literature in Mesopotamia and Israel, Symposium, Society of Biblical Literature, Atlanta.

Cloete, T.T. (red.), 1992, Literêre terme en teorieë, HAUM Literêr, Pretoria. 
Collins, J.J., 1975, 'The court-tales in Daniel and the development of apocalyptic', Journal of Biblical Literature 94, 218-234. http://dx.doi.org/10.2307/3265731

Collins, J.J., 1984, Daniel with an introduction to apocalyptic literature: The Forms of the Old Testament Literature, vol. XX, Eerdmans, Grand Rapids.

Collins, J.J., 1985, 'Daniel and his social world', Interpretation 39, 131-143. http:// dx.doi.org/10.1177/002096438503900203

Collins, J.J., 2002, 'Current issues in the study of Daniel', in J.J. Collins \& P.W. Flint (eds.), The Book of Daniel: Composition and Reception, vol. 1, pp. 1-15, Brill, Boston/Leiden.

Collins, J.J. \& Flint, P.W. (eds.), 2002, The Book of Daniel: Composition and Reception Brill, Boston/Leiden.

Crenshaw, J.L., 2007, 'Beginnings, Endings, and Life's Necessities in Biblical Wisdom' in R.J. Clifford (ed.), Wisdom Literature in Mesopotamia and Israel, Symposium, pp. 93-106, Society of Biblical Literature, Atlanta.

Culley, R.C., 1992, Themes and variations: A study of action in biblical narrative, Scholars, Atlanta, GA. (The Society of Biblical Literature Semeia Studies.)

Davies, P.R., 1985, Daniel: Old Testament Guides, JSOT, Sheffield.

Deist, F.E., 1992, 'Ou Testamentiese Literatuur', in T.T. Cloete (red.), Literêre terme en teorieë, pp. 357-359, HAUM Literêr, Pretoria.

Douglas, J.D. (ed.), 1962, The new Bible dictionary, Inter-Varsity, Leicester.

Eissfeldt, O., 1974, The Old Testament: An introduction: The history of the formation of the Old Testament, transl. P.R. Ackroyd, Basil Blackwell, Oxford.

Feinberg, L. (ed.), 1971, Asian Laughter: An Anthology of Oriental Satire and Humor Weatherhill, New York.

Fewell, D.N., 1991, Circle of sovereignty: Plotting politics in the book of Daniel, Abingdon, Nashville.

Gammie, J.G., 1976, 'The classification, stages of growth, and changing intentions in the book of Daniel', Journal for Biblical Literature 95(2), 191-204. http://dx.doi. org/10.2307/3265236

Good, E.M., 1985, 'Apocalypse as comedy: The book of Daniel', Semeia 32, 41-70.

Griffin, W.V., 1994, s.v., 'Satire', in W.V. Harris (ed.), Dictionary of Concepts in Literary Criticism and Theory, no. 12, pp. 12-24, Greenwood, New York.

Hambidge, J., 1992, s.v., 'Genre', in T.T. Cloete (red.), Literêre terme en teorieë, pp. 148-150, HAUM Literêr, Pretoria.

Harris, D., 1992, Satire: A Critical Reintroduction, University Press of Kentucky, Lexington.

Harris, W.V. (ed.), 1994, s.v., 'Satire', Dictionary of Concepts in Literary Criticism and Theory, Greenwood, New York. (Reference Source for the Social Sciences \& Humanities, no. 12.)

Hartman, L.F. \& DiLella, A.A., 1978, The book of Daniel, Anchor, Manchester.

Heaton, E., 1956, The book of Daniel: Torch Bible Commentaries, SCM, London.

Helberg, J.L., 1994. Die boek Daniël: Skrifuitleg vir Bybelstudent en gemeente, N.G. Kerk-Uitgewers, Kaapstad.

Hengel, M., 1974, Judaism and Hellenism, Fortress, Philadelphia
Humphreys, W.L., 1973, 'A life-style for Diaspora: A study of the tales of Esther and Daniel', Journal of Biblical Literature 92, 211-223. http://dx.doi. org $/ 10.2307 / 3262954$

Joubert, W.H., 1979, 'Power and responsibility in the Book of Daniel', DTh-tesis, Department Old Testament, University of South Africa.

Kirkpatrick, S., 2005, Competing for Honour: A social-scientific reading of Daniel 1-6, Brill, Leiden/Boston.

LaCocque, A., 1979, The book of Daniel, transl. D. Pellauer, SPCK, London.

Licht, J., 1978, Storytelling in the Bible, Magnes, Jerusalem.

Lucas, E.C., 2002, Daniel: Apollos Old Testament Commentary, InterVarsity, Leicester/ Downers Grove.

Martin, R.A., 1998, 'Approaches to the Sense of Humor: A Historical Review', in W. Ruch (ed.), The Sense of Humor: Explorations of Personality Characteristic, pp. 15-60, W. de Gruyter, New York.

Milne, P.J., 1988, Vladimir Propp and the study of structure in Hebrew Biblical narrative, Almond, Sheffield. (Bible and Literature Series.)

Nickelsburg, G.W.E., 1972, Resurrection, immortality, and eternal life in intertestamental Judaism, Cambridge University, Cambridge.

Niditch, S. \& Doran, R., 1977, 'The success story of the wise courtier: A formal approach', Journal of Biblical Literature 96, 179-193. http://dx.doi.org/10.2307/3265877

Porteous, N., 1979, Daniel. Old Testament Library, 2nd edn., SCM, London.

Pretorius, R., 1992, s.v., 'Satire', in T.T. Cloete (red.), Literêre terme en teorieë, pp. 464-465, HAUM Literêr, Pretoria.

Rendtorff, R., 1985, The Old Testament: An introduction, transl. J. Bowden, SCM, London.

Ruch,W. (ed.), 1998, The Sense of Humor: Explorations of Personality Characteristic W. de Gruyter, New York.

Scott, R.B.Y., 1971, The way of wisdom in the Old Testament, Macmillan, New York.

Smith-Christopher, D.L., 1993, 'Gandhi on Daniel 6: Some thoughts on a cultural exegesis of the Bible', Biblical Interpretation 1(3), 321-338.

Smith-Christopher, D.L., 2002, A Biblical Theology of Exile, OBT, Fortress, Minneapolis http://dx.doi.org/10.1163/156851593X00197

Valeta, D.M., 2008, Lions and Ovens and Visions: A satirical reading of Daniel 1-6, Sheffield Phoenix, Sheffield. (Hebrew Bible Monographs, no. 12.)

Van der Toorn, K., 2007, 'Why Wisdom Became a Secret: On Wisdom as a Written Genre' in R.J. Clifford (ed.), Wisdom Literature in Mesopotamia and Israel, Symposium, pp. 21-32, Society of Biblical Literature, Atlanta.

Van der Woude, A.S. (ed.), 1993, The book of Daniel in the light of new findings, Leuven University, Leuven.

Venter, P.M., 1993, 'The Function of Poetic Speech in Daniel 2', HTS Teologiese Studies/ Theological Studies 49, 1009-1020.

White, H., 1978, Tropics of discourse: Essays in cultural criticism, John Hopkins University, Baltimore.

Young, E.J., 1949, A commentary on Daniel, Banner of Truth Trust, London. (Geneva series of commentaries.) 